\title{
Bibliometric evaluation of research on political risks in construction projects
}

\author{
Chunling Wei ${ }^{\mathrm{a}}$, Xiaopeng Deng ${ }^{\mathrm{a}^{*}}$, Tengyuan Chang ${ }^{\mathrm{b}}$, Amin Mahmoudi ${ }^{\mathrm{a}}$ and Safi Ullah ${ }^{\mathrm{a}}$
}

${ }^{a}$ Department of Construction and Real Estate, School of Civil Engineering, Southeast University, 210096 Nanjing, P.R. China ${ }^{b}$ School of Law, Southeast University, Nanjing, China

\section{H R O N I C L E}

Article history:

Received: November 30, 2020

Received in revised format:

April 2, 2021

Accepted: May 18, 2021

Available online:

May 19, 2021

Keywords:

Visual informetrics

Political risk

Web of Science

Overview

Bibliometric evaluation

Construction project

\section{A B S T R A C T}

The current study aims to provide an overview of the research on political risk using the Web of Science (WoS) database as well as summarize research results and put forward some suggestions for research directions of political risk in international construction projects. It is the first time scientometric analysis of political risk research is executed. In this regard, the papers related to political risk in the WoS database have been retrieved and the literature is sorted out by visual and content analysis methods. Visual analysis is used to analyze the research overview, knowledge base, and research hotspots of this field. The content analysis method is adopted to expound the current research focus from three perspectives inducing the influence of political risk, risk assessment, and risk management measures. The results show that in the political risk context, the number of publications has experienced an increasing trend in recent years. Based on the existing literature on political risk for all companies, this overview provides some suggestions to address the political risk in international construction projects in the future. The results contribute to the scholars understanding of the research overview, research hotspots, and future research directions of political risk research in construction projects.

\section{Introduction}

The study of political risk in construction projects has been going on for decades. Based on the previous studies, it is common to define political risk as the risk of adverse consequences due to political events (Root, 1972), government actions (Aliber, 1975), and the negative consequences of political interventions (Zhuang et al., 1998). In the host country, political risk is often caused by uncertainty in the lines of government, political organizations, minority groups, separatist organizations, etc. With the continuous development of economic globalization, the world economic and political landscape are continually changing, and the inducing factors and manifestations of political risk experience an increasing trend as well. Political risk, which affects the operation, profit, and enterprise ownership of multinational enterprises, is a significant factor affecting overseas investment decisions (Jadhav, 2012). Political risk is a massive concern for those enterprises that seek overseas profits (Jakobsen, 2010), and a hot topic in the field of international business (Hood \& Nawaz, 2004). Political risk in international construction projects is due to exposure to the international policies or the host country's policy, economy, environment, social events, and inaction of the government and organizations. It makes the international project management environment uncertain and brings a negative impact on profits or other targets. In recent years, with the gradual deepening of global integration trends and the changing world political landscape, political risk has become a factor that must be considered in the strategic decisions of multinational corporations. The academic community's attention to the political risk context has also increased, which has led to an increase in the research results of political risk significantly. Also, it has been recognized that in a scientific and academic world, the value of an entity (such as the discipline of political risk, in our case) is determined by the quality and

* Corresponding author.

E-mail address: $\underline{\text { dxp@seu.edu.cn (X. Deng) }}$ 
quantity of the research work associated with that entity (Javed \& Liu, 2018). Therefore, overviewing the relevant literature on political risk is useful from many aspects. For example, it can contribute to scholars and academics' understanding of the current situation of political risk research and find out the possible research directions in future. Furthermore, industrial actors can learn from this article concerning political risk, so they can take reasonable strategies to manage it. For young scholars and those students who want to learn this field of study quickly, the current study can be helpful as well.

This paper provides a visual overview of the research on political risk based on the WoS database as well as summarizes research results, and points out the future research direction of political risk in international construction projects. This article has selected the conducted studies related to political risk in the WoS database as the research object and used the visual analysis method to form a quantitative literature overview. CiteSpace (cluster.ischool.drexel.edu/ cchen/citespace/download/, CiteSpace V 5.7 R2) was used to depict the atlas of scientific research cooperation (country (region), institution author), cocitation (cited journal, reference and cited author) and keyword co-occurrence of political risk, and to analyze the research status, knowledge basis and hotspots of political risk research. Moreover, this overview attempts to suggest future research directions of political risk in international construction projects.

The structure of the current study is organized as follows: Section 1 explains the research content and purpose. Section 2 introduces the methodology. Section 3 presents the results of the visual analysis. Section 4 discusses the research content and suggestions. Section 5 summarizes the achievements of this article. We explain each section in detail below.

\section{Methodology}

In this paper, the visual analysis software CiteSpace $\mathrm{V}$ and content analysis method were used to analyze literature on political risk. CiteSpace is a quantitative analysis software based on the Java platform which was developed by Dr. Chen from Drexel University (Chen, 2014). CiteSpace has the function of literature overview and can employ multiple, time-sharing, dynamic, and other visual technologies to show the dynamic characteristics. It can show the changes in research content as well as the evolution trend of the literature over time (Chen, 2006). For example, Wang (2020) analyzed the research progress and development trend of social media based on CiteSpace knowledge graph. Hu et al. (2019) analyzed the research progress on ecological models in the field of water eutrophication using CiteSpace. Pan et al. (2019) employed the CiteSpace to provide a systematic review on the grey system theory from 1991 to 2018. Jiang et al. (2019) made a visual overview by using CiteSpace in the field of ecosystem health. Also, this article chose CiteSpace as a document analysis tool for the political risk research context. The content analysis method is a research method that combines qualitative analysis and quantitative analysis effectively. It mainly takes the content of the research object as the entry point and finally draws qualitative conclusions based on the statistical data (Onwuegbuzie et al., 2009). This paper combined these two methods to analyze the literature on political risk and obtain objective and scientific information on the status and research trends of political risk. The research framework for analyzing the literature on political risk is shown in Fig. 1.

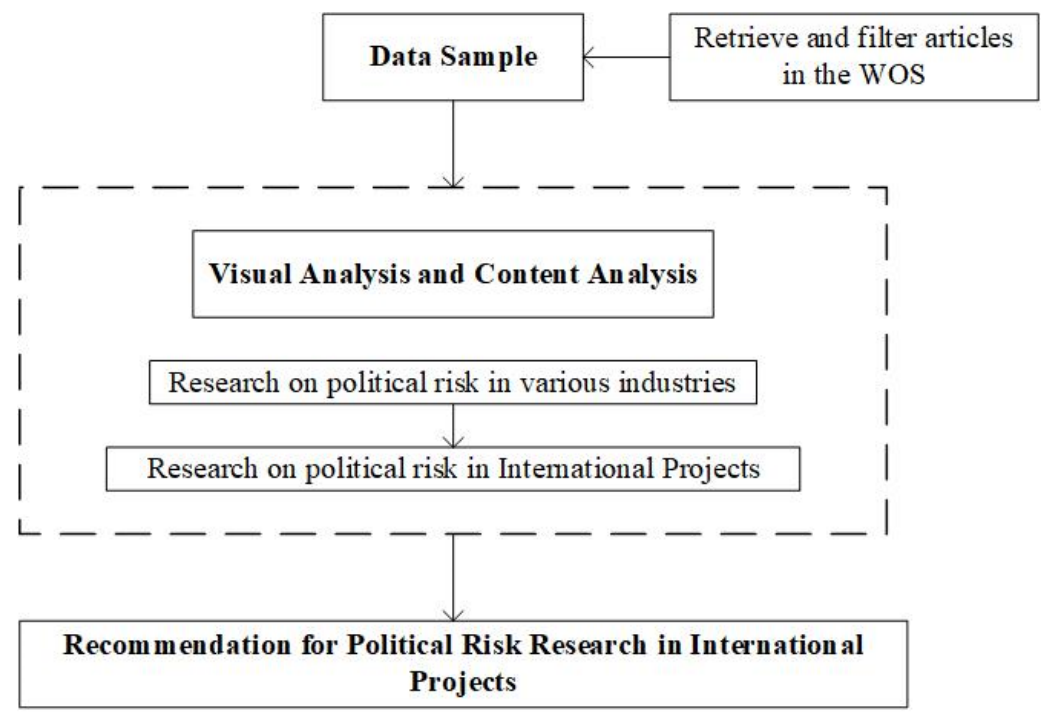

Fig. 1. Research Framework

The representativeness and accuracy of the data set depend on selecting the academic database and the design of the retrieval strategy (Hox \& Boeije, 2005). To ensure the quality of the retrieved data, this research followed the practice of the existing academic community, which was defined as follows: Literature Database: Web of Science Core Collection; Topic: "political risk" or "political risks"; Document Type: Article or Overview; Timespan: 1950-2020; Language: English. After processing 
the above steps, 1403 published documents from 1965 (the earliest year the results were published was 1965) to 2020 (December) were initially retrieved. Despite the above restrictions, there are still many documents that could not meet the research requirements. Hence, the authors further screened the articles and deleted irrelevant documents, which are duplicated documents and not related to political risk in the preliminary search results. Finally, a total of 978 valid documents were obtained (of these articles, no more than $10 \%$ are about "construction project" or "international project", which is a small percentage). The information concerning these papers was considered as samples for data analysis.

The explanations of some essential measures/metrics in this article are provided as follows:

(a) Betweenness centrality

Betweenness centrality is a metric of a node in a network that measures how likely an arbitrary shortest path in the network will go through the node. It can be calculated using the following formula:

$$
B C_{i}=\sum_{a \neq i \neq b} n_{a b}^{i} / g_{a b}
$$

where $g_{a b}$ represents the shortest path from node $a$ to node $b . n_{a b} i$ is the number of shortest paths passing node $I$ in the shortest path from node $a$ to node $b$. The higher the $n_{a b}^{i}$ represented, the higher the mediation centrality of node i and the more critical its position in the network.

\section{(b) Density}

Density is used to describe the density of interconnecting edges between nodes. A network with $\mathrm{N}$ nodes and $\mathrm{E}$ actual edges, whose network density $(d(\mathrm{G}))$ is:

$$
d(\mathrm{G})=\frac{2 E}{N(N-1)}
$$

\section{Visualization Analysis}

\subsection{Research Overview}

\section{(a) Geographical distribution and amount tendency}

Studying the geographical distribution of papers can help researchers to identify countries and regions that are currently progressing in a particular field of research. Moreover, it can help researchers understand the international position of a country in a certain field and find a benchmark country for effective learning. The overview put the sample data into CiteSpace, analyzed the geographical distribution of the papers in the political risk field and the cooperation relationship between researchers in different countries, and obtained the cooperation map of the countries (regions) (See Fig. 2).

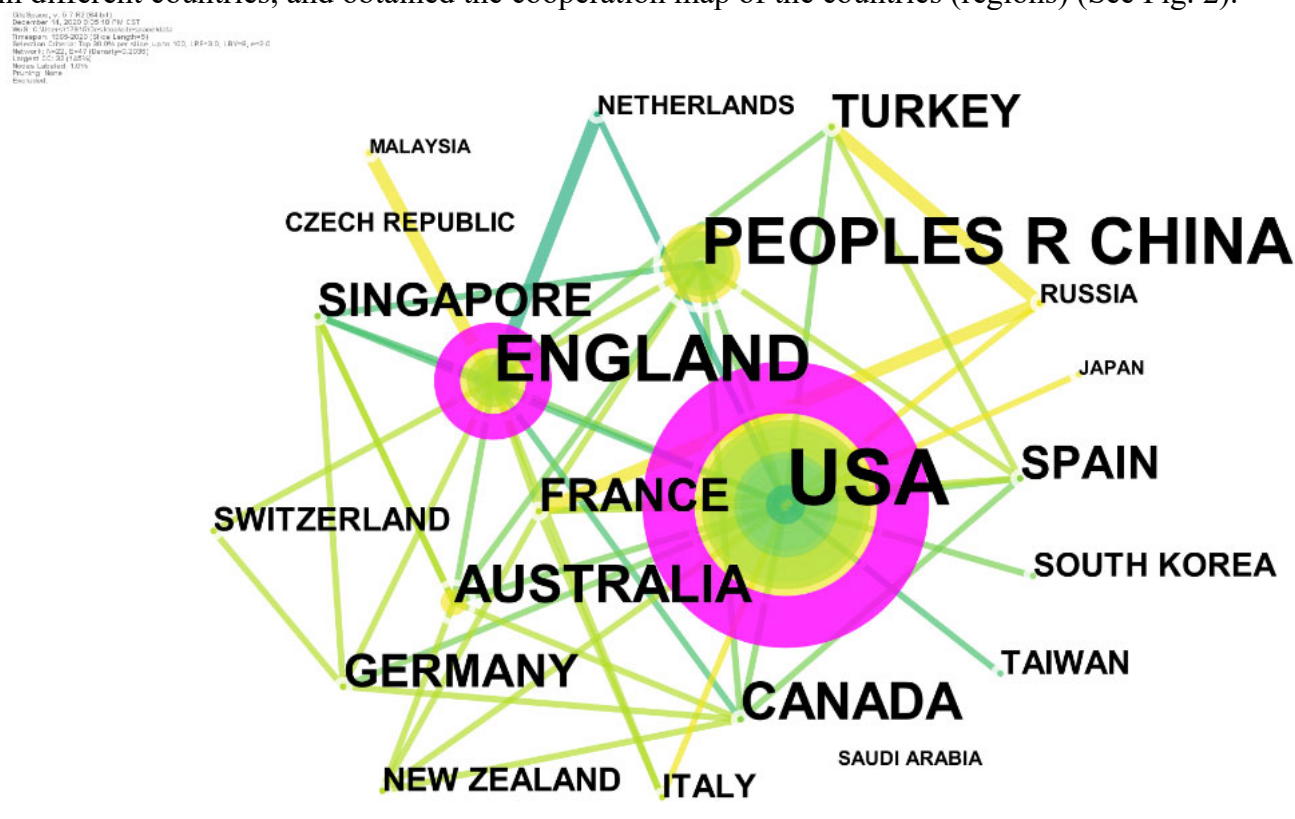

Fig. 2. Country (region) distribution of political risk related papers in WoS

The results show that in the domain of political risk research, the authors from the United States have published the most 
articles compared to others. China achieved the second position, followed by the United Kingdom and Canada. The United States published 290 articles, accounting for $29.65 \%$ of the total number of papers published in the field, with a centrality of 0.56 , which is the world's top level and the core country in the field of political risk. In the 1950s, American scholars proposed the concept of risk management. After that, in 1952, the United States established the "Association of Risk and Insurance Management." Scholars began to pay attention to political risk, mainly focusing on the definition of political risk, the classification and source of political risk, and the assessment and management of political risk.

In terms of research on political risk, the authors of the United States were beginning to study early, published the largest number of articles, and had maintained a leading position. There are many factors that lead to a large number of articles being published in the United States, including research facilities and huge research expenditure. Another critical factor is the number of departments and institutes specialized mainly in political sciences and international business across the country, compared to other countries. The socioeconomic dimension is also of particular influence, especially at the peak of the cold war with the USSR (more concern on political studies and international relations). The United States, as the largest developed country, has always been the most innovative and scientifically influential country in the world. The United States has carried out extensive economic and trade exchanges with other countries since the 19th century, so it has many multinational corporations. Political risk is an unavoidable hot issue for multinational corporations in international expansion. Since the Second World War applied new changes in the world's economic situation, the need for political risk research has become increasingly urgent. To a large extent, practical needs have also promoted research in this field.

Chinese scholars have published more than 100 articles. Chinese scholars' research on political risk is related to the process of China's opening-up. Before the reform and opening-up, there was little research on political risk in China. In 1978, China proposed reform and opening up. Then, Chinese enterprises began to move toward the world stage. In 2001, China joined the World Trade Organization (WTO) and entered a new stage of opening-up. After 2013, the "Belt and Road" initiative was launched. Chinese companies play an increasingly important role around the world. China started late in researching political risk and has been involved in this field just recently. Although a rising star of political risk research, and despite fruitful research in this area in recent years, it has achieved the second position in terms of the number of publications among all countries.

The authors from different countries have focused on different countries and types of political risk. The main concept of political risk in different regions is similar, but different regions are affected by different types of political risks to different degrees. For example, macroeconomic and policy turbulence was the most significant perceived source of risk in Latin America, and excessive bureaucracy was the most significant source of perceived risk in South Asia (Jones and Comunale, 2018).

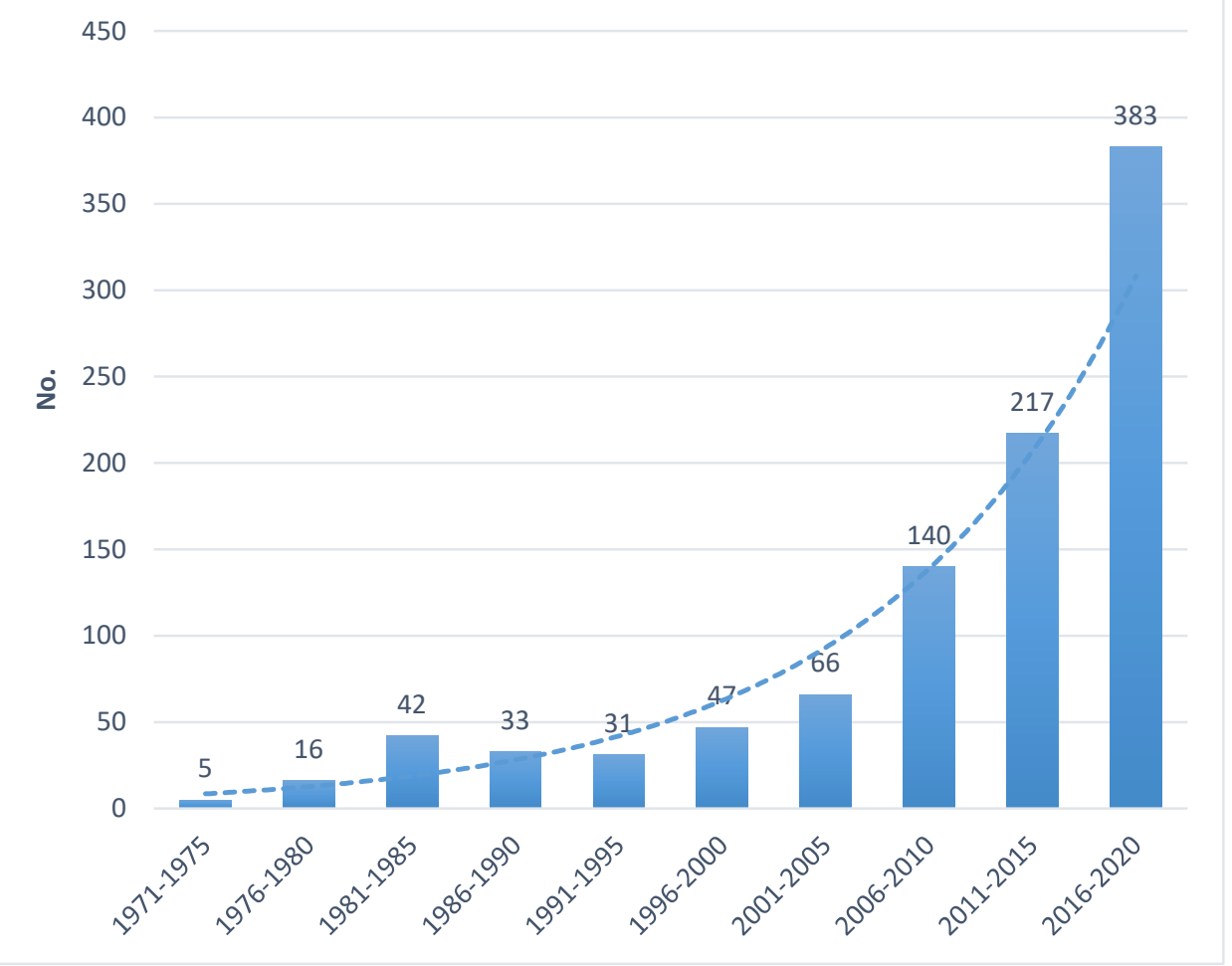

Fig. 3. The number of articles on political risk in WoS, 1970-2020

Fig. 3 shows trends in the number of published articles related to political risk research between 1970 and 2020. Before 1980, academia paid little attention to political risk, while the average number of published articles was about one per year. Between 
1981 and 2000, the academic paid more attention to political risk and published approximately eight articles every year. After 2000, the number of published articles increased rapidly, reaching a maximum of 114 in 2018. Overall, the number of published articles on political risk research has shown an increasing trend, indicating that political risks have attracted widespread attention from scholars. The increased number of scholars in the past few decades, particularly with the increase in the number of universities, is further evidence of the importance of political risk. It is expected that the number of literature on political risk is going to rise in the future. Experts and scholars will conduct more extensive and in-depth research on political risk than nowadays. The causes of political risk are complex and numerous. They not only come from the host country but also the home country, the third country and the global political and economic environment of the transnational enterprise, as well as the relative bargaining power between the host country government and the transnational enterprise (Haner, 1979; Ramamurti, 2001). Under the new global economic and political pattern, the protectionism of international direct investment has become a countercurrent to the general trend of the free flow of global capital (Sauvant, 2015). For the situation that the domestic and foreign investment environment of various countries is becoming more and more severe and complicated, the inducing factors of political risk and the forms of risks are more diverse (Graham et al., 2016). The scope of influence is expanding.

\section{(b) Institution Distribution}

According to the collected samples, the author's institution was analyzed to obtain the academic achievements and cooperative relations between institutions carrying out political risk research (Fig. 4).

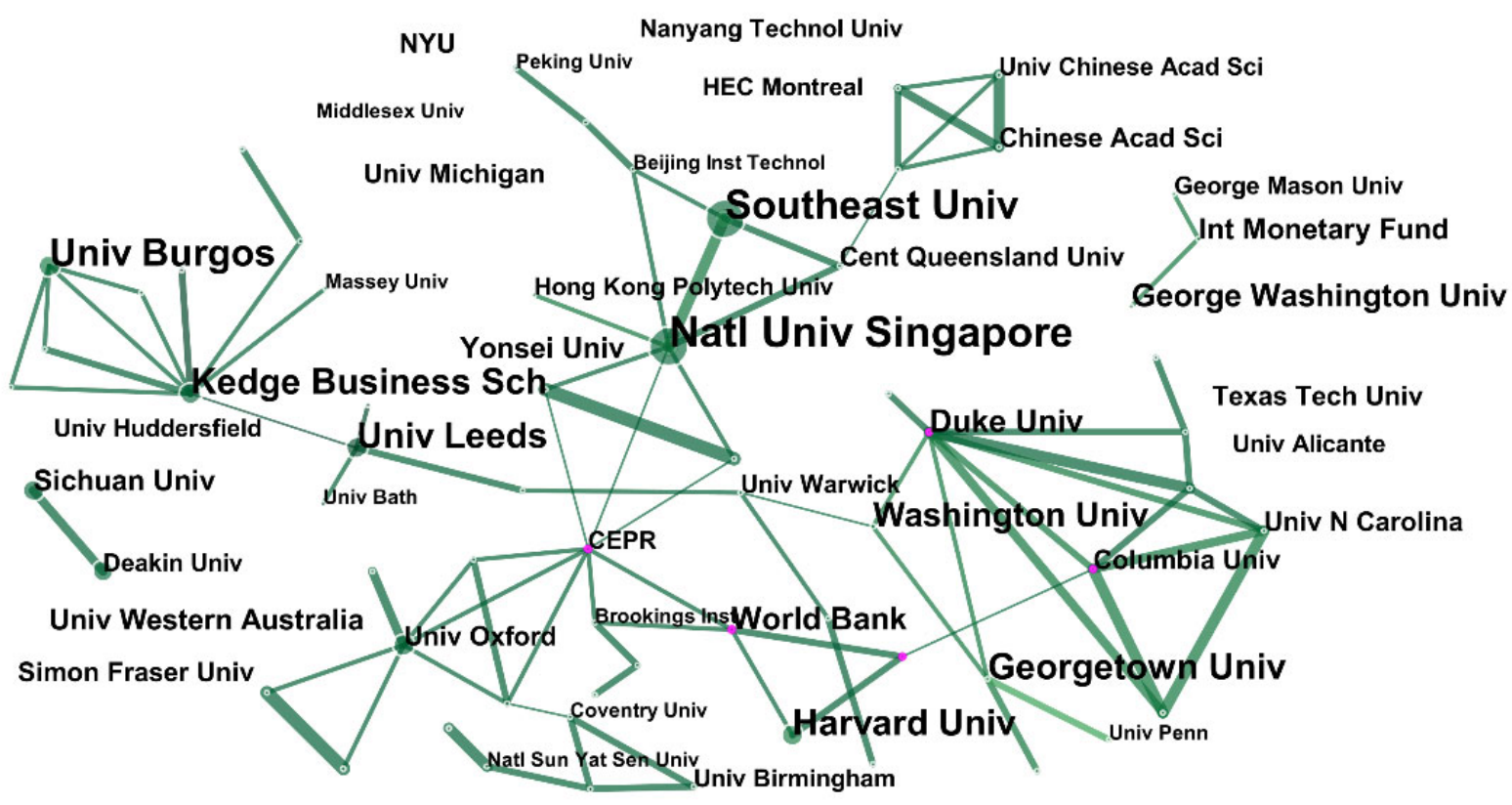

Fig. 4. Institution distribution of political risk related papers in WoS

Table 1

Top 10 institutions for political risk research publications

\begin{tabular}{cccc}
\hline Frequency & Institution & Nation & Year \\
\hline 16 & National University of Singapore & Singapore & 2007 \\
13 & Southeast University & China & 2011 \\
11 & Burgos University & Spain & 2010 \\
10 & Kedge Business School & France & 2017 \\
9 & Harvard School & USA & 2006 \\
9 & University of Leeds & England & 2005 \\
9 & Georgetown University & USA & 2000 \\
8 & Washington University & USA & 2005 \\
7 & Duke University & China & 2010 \\
7 & Wuhan University of Technology & & 2010 \\
\hline
\end{tabular}

Notice: "Year" means the first year the agency published a study of political risk.

As shown in Fig. 4 and Table 1, most of the author's institutions are universities and scientific research institutions, while few 
are administrative and other institutions. World Bank (7 articles) and International Monetary Fund (7 articles) are the top two non-school organizations in the number of published articles, accounting for only a small percentage of the total. Colleges and universities have the advantages of disciplines and talents, have accumulated the enormous potential of science and technology, and are an essential base for the development of scientific research. They occupy a fairly important position in the scientific research of various countries. From a historical perspective, many important academic centers in some European and American countries were built in famous universities, and many significant studies are inseparable from some famous universities. Also, the increase in the number of universities is rapid, so their strength is highly apparent. The scientific research strength of the administrative agencies is relatively weak, so the articles are few. It also suggests that other external partners (e.g., industry, civil society, etc.) should work closely with academics in the academic field.

\section{(c) Author Analysis}

To some extent, the number of papers published by researchers reflects their knowledge output capacity. By analyzing the author's cooperation network, researchers' contributions and their cooperative relationships can be understood. CiteSpace can be used to analyze the author's work and get his/her cooperation maps (Fig. 5).

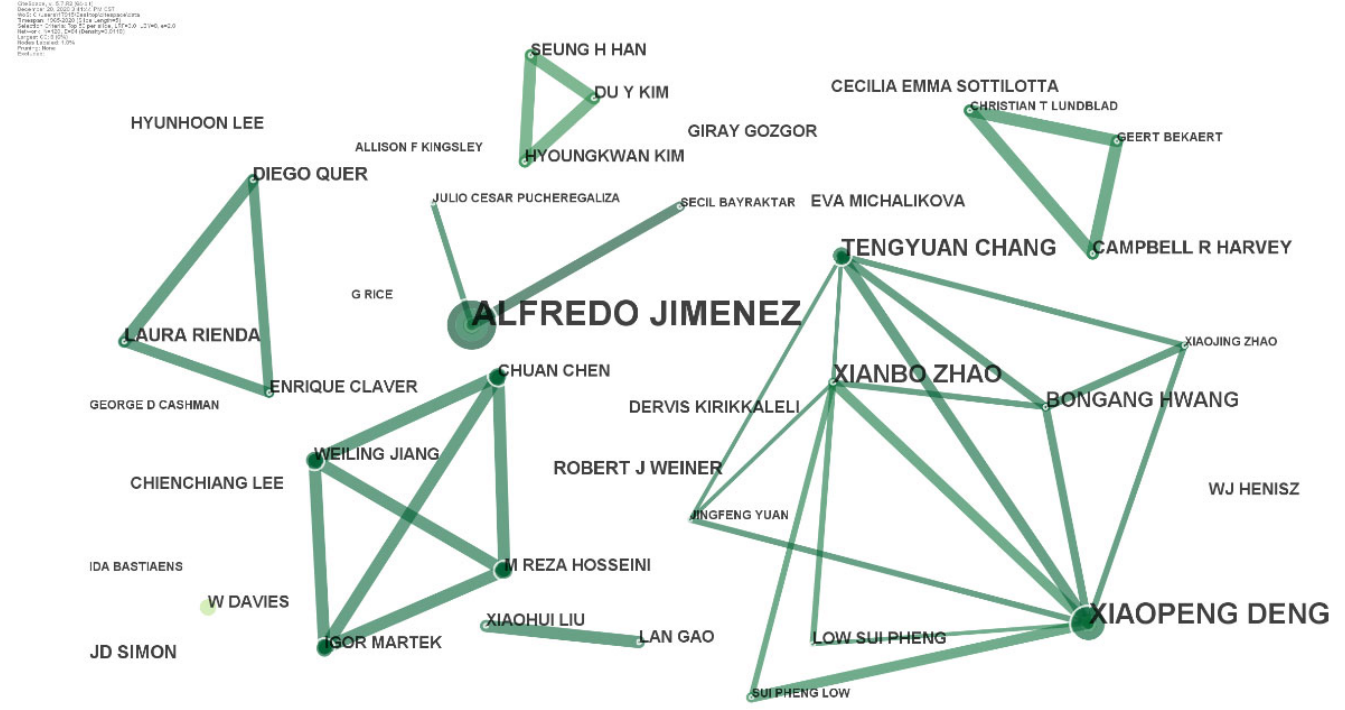

Fig. 5. Author collaboration graph of political risk related papers in WoS

As can be seen from Fig. 5, the scholars who published the most articles are Alfredo Jimenez from Grenoble Business School, followed by Xiaopeng Deng from Southeast University, Xianbo Zhao from the National University of Singapore, and Tengyuan Chang from Southeast University. Deng, Zhao, and Chang have extensive relationships with other authors in the research field of political risk. Jimenez's research on political risk mainly includes the following three aspects: (1) the impact of political risk on foreign direct investment (Jiménez et al., 2018); (2) the relationship between corruption and the rate of creation of multinational enterprises (Jiménez et al., 2017; Jiménez and Alon, 2018); (3) the impact of political risk on the internationalization strategy of multinational corporations (Jiménez, 2010; 2011). Deng conducted a comprehensive study on the political risk of international construction companies and international construction projects, pointed out the key variables and factors of political risk (Deng et al., 2014b; Deng et al., 2018), and proposed counter measures (Deng et al., 2014a). Zhao's study on risk was abundant, including both the risks associated with the use of BIM technology (Zhao et al., 2018) and the risks of corporate management (Zhao and Singhaputtangkul, 2016). Their research on political risk mainly involves multinational construction companies and has made outstanding contributions to risk identification. Further analysis reveals that most of the high-yield researchers are college scholars, who are well-known in the field of project research. Most of their research is on the political risk involved in the field of international construction projects, indicating that political risk in international construction projects is one of the focuses of scholars. This is related to the combination of political risk and various risks inherent in the project itself. Political risk reflects distinct industry characteristics, so it is imperative to conduct professional research on international construction projects.

\subsection{Knowledge Base}

The knowledge base is the track of citation and co-citation in the scientific literature (Cronin, 2001). By analyzing the citations, we can understand the literature, authors, and journals that play an essential role in the domain of political risk research and clarify the knowledge base of political risk research. In the co-citation analysis of the literature, co-citation of the author, and co-citation analysis of the journal, the size of the nodes represents the number of times the literature, author, or journal is cited, the color of the line represents the time of the first co-citation (Chen, 2014). 
When two references appear in the citation of the third one at the same time, the co-citation relationship is established. The number of times they appear together is defined as the frequency of co-citation. Reference co-citation analysis can be used to analyze potential knowledge structures and to reveal the number and authority of the documents cited in published papers. It can also be used for visualization in scientific research, detecting emerging content, and predicting future research directions.

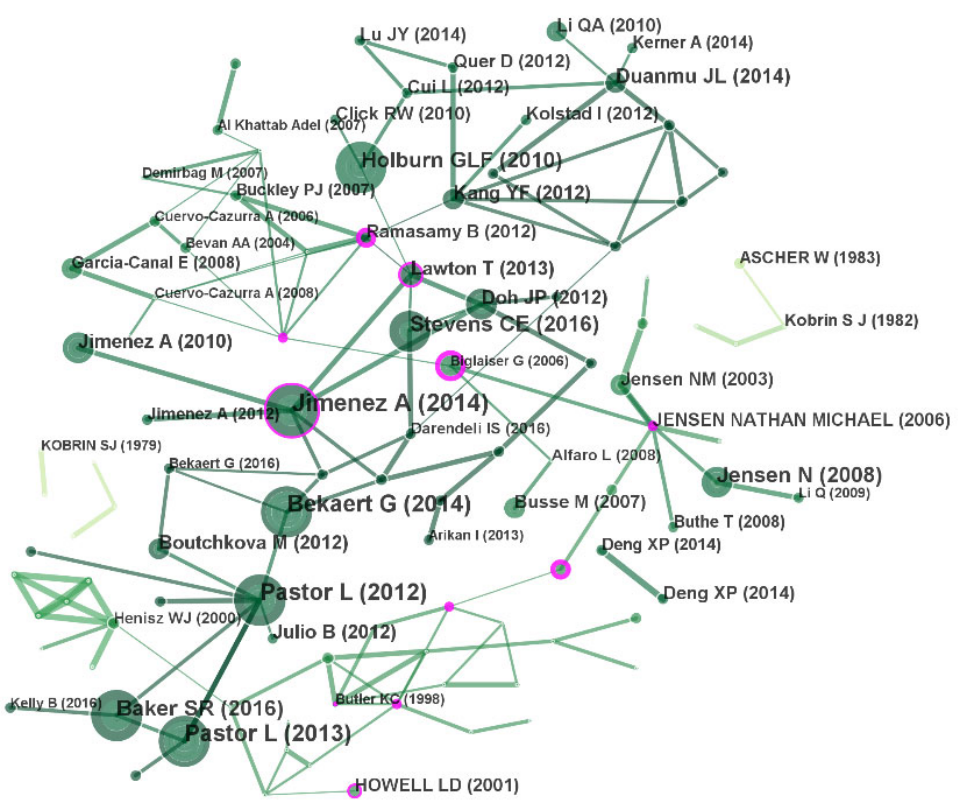

Fig. 6. Reference co-citation graph of political risk related papers in WoS

Fig. 6 shows the co-citation analysis network map of political risk research from 1965 to 2020 . There are many nodes and links in the figure after the initial operation of the software; hence, the option "pathfinder" and "pruning sliced networks" are checked with running the software again. The same procedure is used when analyzing cited authors, cited journals, and keywords. The nodes in the map represent the reference. The larger size of the nodes means the more frequent reference is cited. These key references have laid the foundation for political risk research. Table 2 and Table 3 listed the top key node papers according to the number of co-citation frequencies about political risk and political risk in international construction projects, respectively.

Table 2

Top 10 cited pieces of literature in the field of political risk research

\begin{tabular}{lcc}
\hline \multicolumn{1}{c}{ Title } & & Journal \\
\hline $\begin{array}{l}\text { The influence of political risk on the scope of inter- } \\
\text { nationalization of regulated companies: Insights } \\
\text { from a Spanish sample }\end{array}$ & (Jimenez, 2014) & Journal of World Business \\
$\begin{array}{l}\text { Uncertainty about Government Policy and Stock } \\
\text { Prices }\end{array}$ & (Lubos,2012) & The Journal of Finance \\
$\begin{array}{l}\text { Political risk spreads } \\
\text { Political uncertainty and risk premia }\end{array}$ & (Bekaert,2014) & Journal of International Business Studies \\
$\begin{array}{l}\text { Toward a legitimacy-based view of political risk: } \\
\text { the case of Google and Yahoo in China }\end{array}$ & (Pástor,2013) & Journal of Financial Economics \\
$\begin{array}{l}\text { Measuring economic policy uncertainty } \\
\text { Political capabilities, policy risk, and international } \\
\text { investment strategy: evidence from the global elec- } \\
\text { tric power generation industry }\end{array}$ & (Scott,2016) & Strategic Management Journal \\
$\begin{array}{l}\text { Political risk, democratic institutions, and foreign } \\
\text { direct investment }\end{array}$ & (Jensen,2008) & Quarterly Journal of Economics \\
$\begin{array}{l}\text { State-owned MNCs and host country expropriation } \\
\text { risk: The role of home-state soft power and eco- } \\
\text { nomic gunboat diplomacy }\end{array}$ & (Duanmu,2014) & Strategic Management Journal \\
$\begin{array}{l}\text { Does political risk affect the scope of the expansion } \\
\text { abroad? Evidence from Spanish MNEs }\end{array}$ & (Jiménez,2010) & Journal of International Business Studies \\
\hline
\end{tabular}


Table 3

Top cited pieces of literature on political risk in international construction projects

\begin{tabular}{|c|c|c|}
\hline Title & & Journal \\
\hline $\begin{array}{l}\text { Discriminant analysis for predicting ranges of cost var- } \\
\text { iance in international construction projects }\end{array}$ & (Kim et al., 2008) & $\begin{array}{l}\text { Journal of Construction Engineering } \\
\text { and Management }\end{array}$ \\
\hline $\begin{array}{l}\text { Project System Vulnerability to Political Risks in In- } \\
\text { ternational Construction Projects: The Case of Chinese } \\
\text { Contractors }\end{array}$ & (Deng et al., 2014b) & Project Management Journal \\
\hline $\begin{array}{l}\text { Political Risks in Central Asian Countries: Factors and } \\
\text { Strategies }\end{array}$ & (Chang et al., 2018a) & $\begin{array}{l}\text { Journal of Management in Engineer- } \\
\text { ing }\end{array}$ \\
\hline $\begin{array}{l}\text { Entry Mode Taxonomy and Choice of Chinese Interna- } \\
\text { tional Construction Companies }\end{array}$ & (Jia et al., 2017) & $\begin{array}{l}\text { Journal of Management in Engineer- } \\
\text { ing }\end{array}$ \\
\hline $\begin{array}{l}\text { Root Causes of Recurring Contractual Conflicts in In- } \\
\text { ternational Construction Projects: Five Case Studies } \\
\text { from Vietnam }\end{array}$ & $\begin{array}{l}\text { (Maemura et al., } \\
\text { 2018) }\end{array}$ & $\begin{array}{l}\text { Journal of Construction Engineering } \\
\text { and Management }\end{array}$ \\
\hline $\begin{array}{l}\text { Public, private partnerships (PPP) in the developing } \\
\text { world: mitigating financiers' risks }\end{array}$ & (Owolabi et al., 2019) & $\begin{array}{l}\text { World Journal of Science Technology } \\
\text { and Sustainable }\end{array}$ \\
\hline $\begin{array}{l}\text { The Use of Arbitration in Loan Agreements in Interna- } \\
\text { tional Project Finance: Opening Pandora's Box or an } \\
\text { Unexpected Panacea? }\end{array}$ & (Davies, 2015) & Journal of International Arbitration \\
\hline $\begin{array}{l}\text { Strategy development using TOWS matrix for interna- } \\
\text { tional project risk management based on prioritization } \\
\text { of risk categories }\end{array}$ & (Dandage et al., 2019) & $\begin{array}{l}\text { International Journal of Managing } \\
\text { Projects in Business }\end{array}$ \\
\hline
\end{tabular}

Articles at key nodes have expanded the research direction in the field of political risk or made up for the shortcomings of existing research, and promoted the research progress of political risk, which has had a broad impact on subsequent research. For example, Holburn and Zelner (2010) broke through the traditional view that multinational companies invest less in host countries if they face policy risks. They proposed and proved that the weak institutional policy risks stemming from host country policymakers do not hinder foreign direct investment of multinational corporations as traditionally argued and may attract foreign direct investment. The conclusions of the study expanded the concept of the source and nature of international competitive advantage and opened up new horizons for the study of political risk. Given the data problems in existing research, we can only indirectly prove the relationship between political institutions and political risk. Deng et al. (2014a) discussed the variables affecting the vulnerability of project systems to political risks of international construction projects and provided a method to measure the vulnerability of project systems to political risks.

\section{(b) Cited Author Analysis}

When two authors appear in the citation list of the same paper simultaneously, the two authors are deemed to be co-cited. By analyzing the co-citation author, the author of a research field can be identified. The higher number of cited authors represents a broader impact on political risk research. The number of published papers by a researcher can reflect their academic ability directly in a certain period. Nevertheless, the quality of their publication cannot be fed back through the number of publications. Therefore, this paper adopts the cited author analysis to obtain high-impact authors in the field of political risk research. Selecting "Cited Author" in the CiteSpace software node, runs the software to get the author's co-citation map (See Fig. 7), and counts the authors who have been cited more than 60 times (Table 4).

Table 4

High cited authors in the field of political risk (with respect to the "political risk" topic)

\begin{tabular}{ccccc}
\hline Number & Frequency & Centrality & Author & Year \\
\hline 1 & 163 & 0.55 & Kobrin SJ & 1981 \\
2 & 126 & 0.50 & Henisz WJ & 2000 \\
3 & 74 & 0.08 & Li Q & 2005 \\
4 & 66 & 0.11 & Alesina A & 1992 \\
5 & 64 & 0.15 & Bekaert G & 1995 \\
6 & 55 & 0.01 & Busse M & 2010 \\
7 & 51 & 0.05 & Dunning JH & 2005 \\
8 & 50 & 0.15 & Delios A & 2000 \\
9 & 46 & 0.11 & Jensen NM & 2010 \\
10 & 46 & 0.03 & & 2015 \\
\hline
\end{tabular}




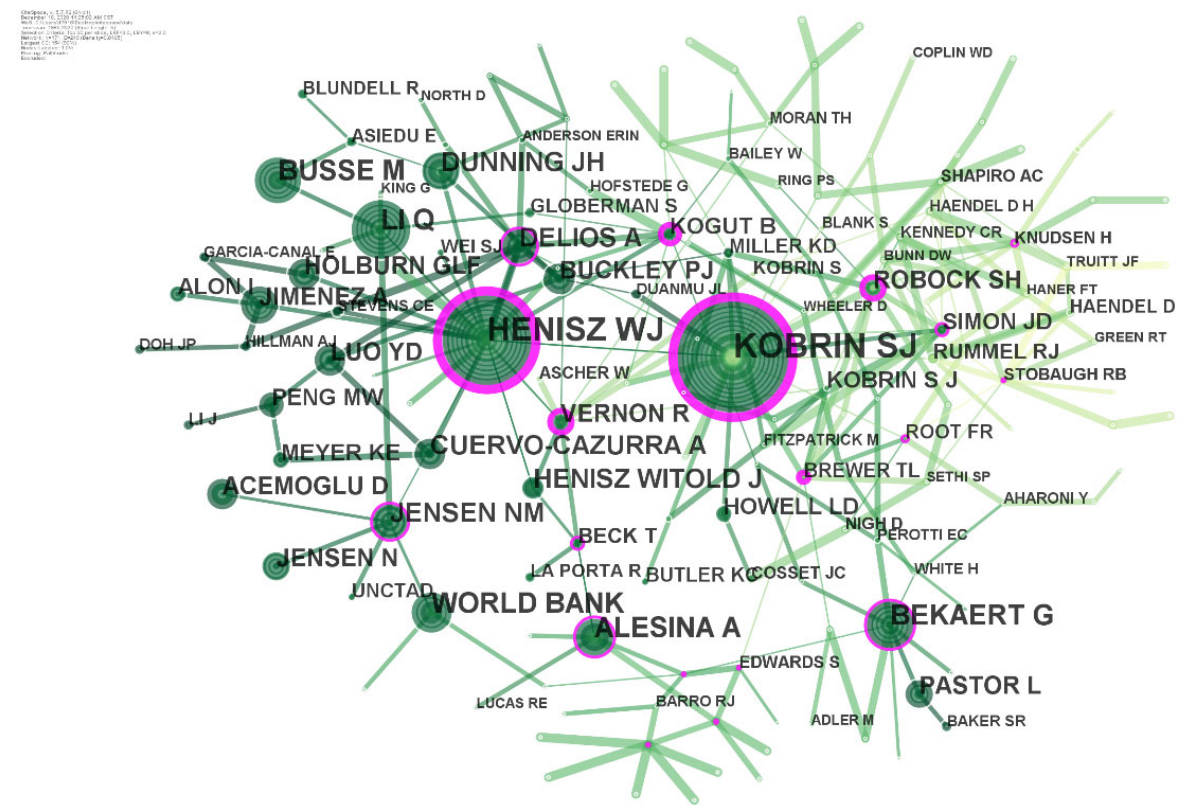

Fig. 7. Co-cited graph of authors of political risk related papers in WoS

In the author's cited network, the top two of the total citation frequencies were Kobrin and Henisz, which are cited more than 100 times. Besides, as shown in Table 6, Kobrin has the highest network center degree (0.55) in the co-citation network. His research on political risk assessment of multinational corporations laid an important foundation for political risk management. The network centrality of the three authors, Alesina, Bekaert, and Jensen, is also above 0.1 . They are at the core status of the research in the field of political risk.

\section{(c) Cited Journal Analysis}

Cited Journal Analysis is an analytical method based on literature co-citation analysis and author co-citation analysis, which can reveal the interaction between different journals and their dependence on each other. The orientation of highly cited journals often reflects the topic. Studying this topic can help scholars comprehend the journals that contributed a lot to academics during this period. High centrality shows the source of knowledge in political risk. The number and density of connections of each node reflect the degree of co-citation of this journal, which is the academic status of the journal in the field of political risk research. By performing a co-citation analysis of the sample data, a knowledge map, as shown in Fig. 8, is obtained.

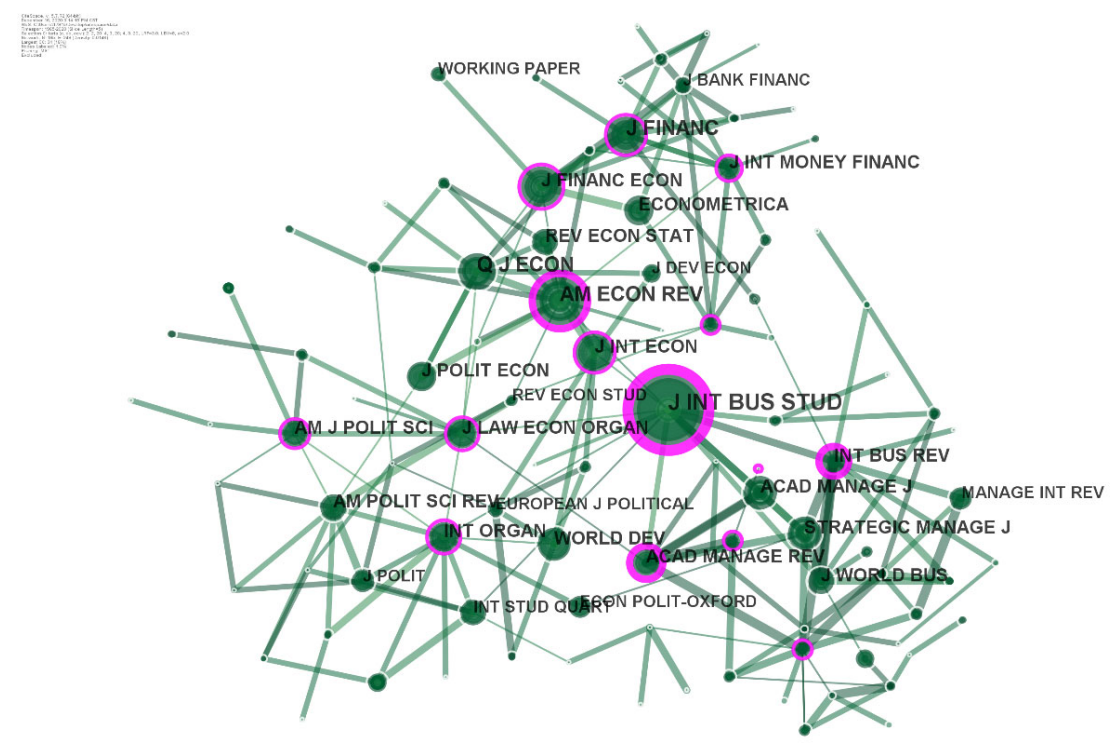

Fig. 8. Co-cited graphs of journals of political risk related papers in WoS 
Network centrality and co-citation frequency are important indexes to determine the core journals in a particular research field. According to the statistics of the citation frequency of journals, the cited journals in the field of political risk research were shown in Table 4. The top ten journals were cited more than 120 times. It can be seen from Figure 8 and Table 4, "Journal of International Business Studies" was the most prominent node, with a frequency of 293 and a center degree of 0.45 , indicating that it has an important role in this field. Academy of Management Review was cited infrequently, but its network centrality was significant (network centrality is 0.21 ), it is also an important journal in the field of political risk research. Table 5 lists the highly cited journals in the field of political risk research and their research fields.

Table 5

Main cited journals of political risk research

\begin{tabular}{lccl}
\hline \multicolumn{1}{c}{ Journal } & Frequency & Centrality & \multicolumn{1}{c}{ Research Areas } \\
\hline Journal of International Business Studies & 293 & 0.45 & Business、Management \\
\hline American Economic Review & 214 & 0.25 & Economics \\
Quarterly Journal of Economics & 158 & 0.08 & Economics \\
Journal of Finance & 153 & 0.10 & Economics、Business、Finance \\
Journal of Financial Economics & 143 & 0.11 & Business、 Economics \\
\hline Journal of International Economics & 139 & 0.12 & Economics \\
International Organization & 128 & 0.14 & International Relations \\
Econometrica & 126 & 0.01 & Business \& Economics \\
Academy of Management Review & 125 & 0.21 & Business \& Management \\
Academy of Management Journal & 124 & 0.01 & Business \& Economics \\
\hline
\end{tabular}

As can be seen from the research fields of these journals, political risk mainly involves four fields: business, economy, finance and management. Journal of International Business Studies has high cited frequency and centrality. Its research areas are business and management, which are the main fields of research on political risk. The cited frequency of American Economic Review is less than the Journal of International Business Studies, and its centrality is high. It means that political risk is common in international relations. Risks cannot be avoided entirely when investing in business or finance. The most inherent hazard from risk is economic loss, and political risk is not an exception. Therefore, the management of political risk is particularly important in the business and financial sectors.

\subsection{Hotspots and Trends}

As a widely concerned research field, it is of great guiding significance to grasp the research hotspots and research frontiers on political risk. There are many ways to identify research hotspots, such as word frequency statistical analysis (using highfrequency keywords to reflect research hotspots), word co-occurrence method (using co-occurrence frequent word clustering to reflect hot research topics) and co-citation clustering methods (using larger clusters to reflect hot research topics). This paper used the word frequency statistical analysis method, which reflects the research hotspots through high-frequency keywords. Keywords are the summary and refinement of the article content by the author, which can reflect the core content of the literature. Therefore, they can help readers quickly grasp the research focus of an article. By statistical and co-occurrence analysis of the keyword frequency in a paper, the research hotspots and research trends in this field can be effectively obtained.

This article applied CiteSpace V to analyze the keywords of the collected sample documents. The node type was selected "keyword", the time partition was "1965-2020", the time interval was " 5 " years. No more than one percent of the articles here have no keywords, and because of the requirements of the software, the less frequent keywords are not displayed. The keywords in the analysis results are some important ones, so the article without keywords has less influence on the analysis results, and the existing keywords can basically represent the research trend. Due to the differences in keyword selection among literature authors, some keywords might be expressed in different forms with the same meaning (such as "FDI" and "Foreign Direct Investment"). In order to clarify the research hotspots of political risk, the above keywords were combined by software, and the resulting keyword co-occurrence map was shown in Fig. 9.

In Fig. 9, the connections between the nodes were close with a few isolated points, which indicates that the research on political risk is mostly concentrated on similar fields. Fig. 9 shows that the keyword "political risk" appears most frequently, which is related to its retrieval as a subject term. From the perspective of the overall research content of the literature, the hotspot keywords contained in Figure 9 include not only the risk types of political risks: "corruption", "policy risk", "terrorism", "civil war", etc., but also the research area: "developing country", "emerging market". There are always specific correlations between various types of risks. The keyword co-occurrence map shows that "country risk", "economic risk" and "financial risk" are also included in the research related to political risk.

To visualize the development trend of political risk research, based on the keyword co-occurrence map, click on "Timeline View" to generate a hotline timeline view of the domain (Fig. 10). 


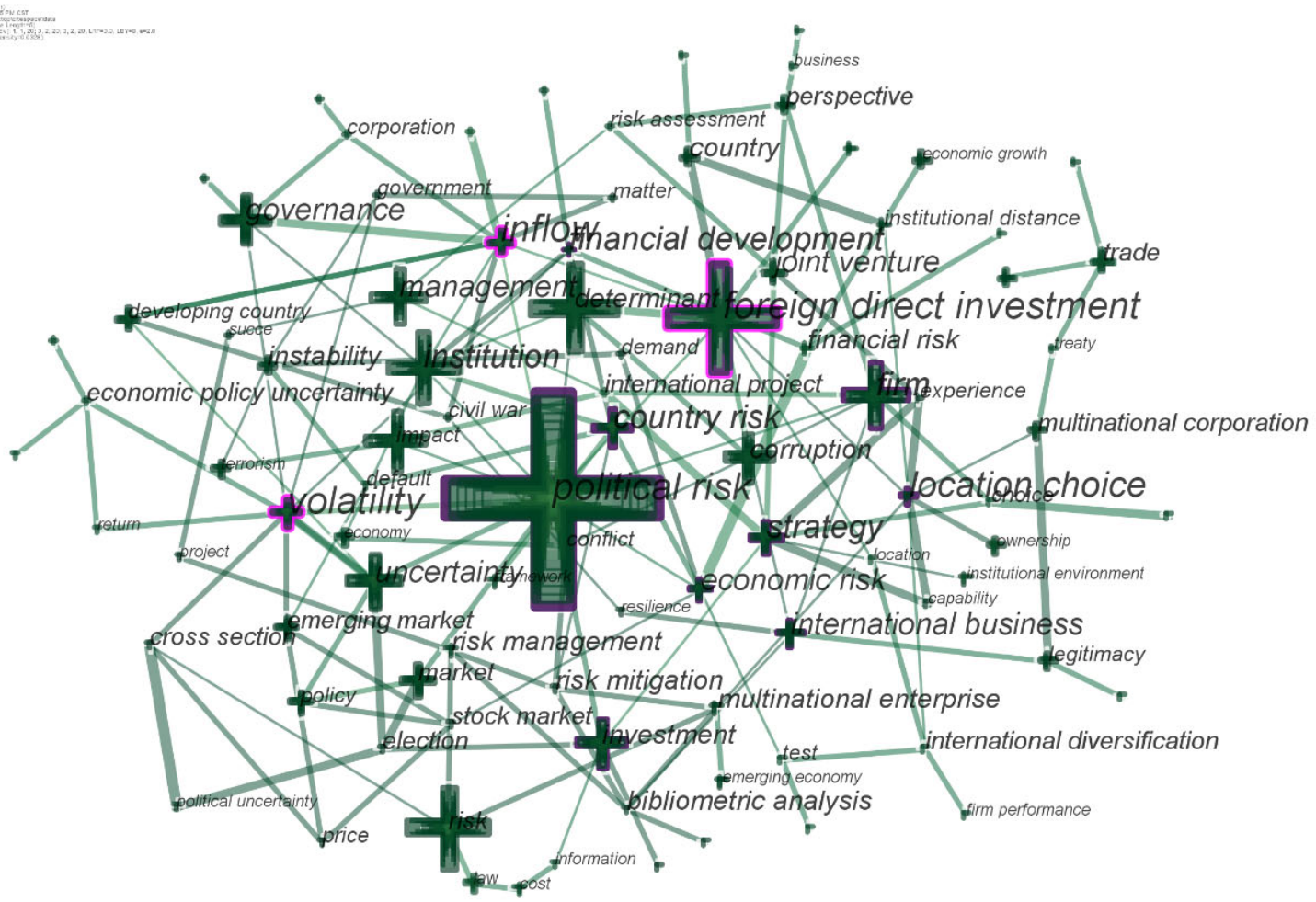

Fig. 9. Keyword map of political risk related papers in WoS

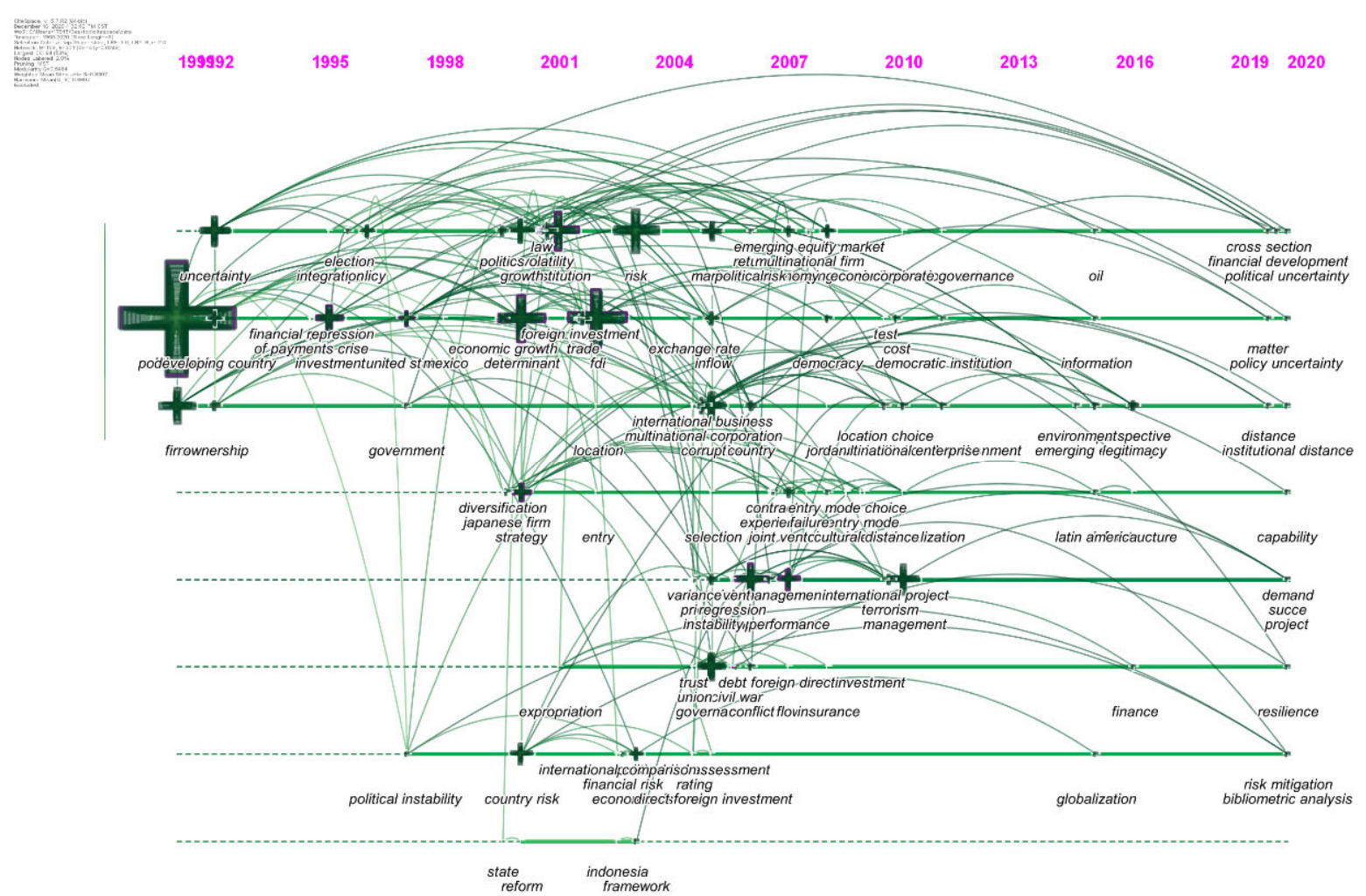

Fig. 10. A timeline view of keyword co-occurrence network: 1965-2019

According to Fig. 3, the number of published articles on the political risk between 1965 and 1990 is small. The operation of 
CiteSpace is limited by software extraction information, analysis information algorithms, and functions. However, the threshold of software operation is adjusted at different values, and there is still no map that reflects the characteristics of political risk research during this time period. The characteristics of this period of research can only be summarized by literature reading. It can be seen from Figure 10 that since 1990, popular research topics in this field have been abundant. In the 1960s and 1970s, political risks were mainly characterized by nationalization and the confiscation of foreign assets (Robock, 1971). In the 1980s and 1990s, the host country's debt problem was caused by the oil crisis and the Iranian revolution was an important factor of political risk (Kassicieh and Nassar, 1982). The manifestation of political risk was discriminatory government intervention, including policy change and political resistance. From 1990 to 2000, the main forms of political risk were expropriation, nationalization, and policy changes. At the beginning of the 21 st century, corruption and terrorism became essential factors in political risk. Civil war and international conflict have also become the focus of attention in the field of political risk. The study of political risk is always combined with foreign direct investment and multinational companies. The impact of political risk on foreign direct investment and multinational corporations is complex and omnifarious, and sufficient attention should be given to it. Recently, the nationalization decisions of some Latin American populist governments have had a severe impact on the business environment of the countries concerned (Sottilotta, 2015), which will lead to nationalization becoming the focus of research once again. Meanwhile, terrorism is an obstacle to foreign direct investment (FDI) inflow (Lee, 2016). In recent years, there have been frequent terrorist incidents and wars in the world. How to deal with such risks is a problem worthy of attention.

In recent years, with the continuous development of economic globalization, the economic and trade cooperation among countries in the world has become more and more frequent. With the world situation becoming progressively more tanglesome, researchers have gradually started to conduct research from different research perspectives, taking countries in different regions as research objects. It shows that the study of political risk pays more attention to the combination of theory and practice. The existing research results can provide references and new ideas for researchers and suggestions or strategies for the managers of multinational enterprises.

\section{Discussion}

\subsection{Status of Political Risk Research}

\section{(a) Research on the impact of political risk}

The existing literature had extensively studied the impact of political risks on foreign direct investment. The focus of early academic research was the foreign direct investment of developed countries. It was generally believed that political risks in host countries hurt international direct investment (Busse, 2004; Easterly et al., 2004; Bunyaratavej \& Hahn, 2007; Duanmu and Guney, 2009; Malhotra \& Zhu, 2009; Duanmu, 2012; Kang \& Jiang, 2012; Ramasamy et al., 2012; Al-Khouri, 2015). Nevertheless, some empirical studies had shown that in some developing countries, such as China, foreign direct investment showed the characteristics of "preference" into countries with high political risk (Buckley et al., 2010; Kolstad and Wiig, 2012; Ramasamy et al., 2012). Yasuda (2020) revealed that if the political risk of the host country is lower than (above) the reference point, multinational companies will interpret the political risk of the host country as an opportunity (threat). Wei (2000) studied the relationship between FDI inflow and corruption degree of the host country by using bilateral data of 12 home countries and 45 host countries and concluded that the higher corruption degree of the host country obtained the less FDI inflow. Hajzler (2014) pointed out that the natural resource abundance of the host country may affect the relationship between the quality of the host country system and FDI inflows. Empirical studies showed that in countries with abundant natural resources, although the quality of the legal system is terrible, there is no adverse effect on the inflow of FDI. Research by Kluge (2017) showed that in Laos, foreign investors were initially popular, but when the market competition with the domestic elite became fierce, the political risk was higher. López-Duarte and Vidal-Suárez (2010) analyzed the influence of cultural distance and political risk on the choice of overseas investment entry mode. They proved that when the FDI environment was characterized by high political risk and high cultural distance, joint ventures were more favored than wholly-owned subsidiaries. Nevertheless, this preference only occurs when there is no language barrier between partners. Mohammad (2020) found that political risk is adversely associated with bank stability in the Middle East and North Africa region.

It could be seen from the above that the political risk of the host country has different effects on foreign direct investment, and there is no consistent conclusion. The political risk posed a threat to multinational companies and might also be a source of opportunity (Jiménez et al., 2014). Various risk factors interact with each other. When analyzing the influence of political risk, it is necessary to combine other risk factors for joint analysis. Meanwhile, it is necessary to make decisions in combination with the internal and external environment when making a foreign investment.

\section{(b) Research on political risk assessment}

Risk assessment is a significant part of risk management, and the assessment results can help decision-makers to: 1) understand the risk accurately; 2) ensure the rationality of target planning and the feasibility of the plan; 3) reasonably choose risk countermeasures and form the best risk countermeasures combination. In the risk assessment, various operational methods 
can be used, including knowledge-based analysis methods, model-based analysis methods, qualitative analysis and quantitative analysis. Before risk assessment, risk indicators should be selected, and a scientific and comprehensive evaluation index system is the premise of reasonable assessment (Song et al., 2010). In the choice of indicators, the methods adopted by scholars include: drawing on the global evaluation system (Jiang et al., 2019), such as International Country Risk Guide index; literature overview (Alamgir et al., 2017); Delphi method (Dinar et al., 2004); questionnaire survey (Gao and Hong, 2017) and interviews (Mazher et al., 2018).

Scholars have used a variety of methods to quantify risk. Tsai and $\mathrm{Su}$ (2005) used the analytic hierarchy process (AHP) to quantify the key risk indicators affecting operators' business and political risk of Taiwan's aviation logistics hub development, respectively. Li et al. (2016) combined the AHP and entropy weight method to make a quantitative assessment of the overseas investment risk of shale gas. Duan et al. (2018) constructed a fuzzy comprehensive evaluation model based on entropy weight and evaluated the energy investment risks of 50 countries along the "Belt and Road". Herrero et al. (2011) used the relevant applications of artificial neural network models to identify and analyze the political risk levels of countries and businesses. In order to study the relationship between Precarious Politics and Return Volatility, Boutchkova et al. (2012) calculated the data related to political risk influencing factors and quantified political risk. Most scholars tend to use qualitative and quantitative methods to assess political risk.

Only a few scholars have used qualitative methods to study political risk. For example, Oetzel (2005) used a qualitative research design to assess the political risk of Costa Rica through personal interviews with managers. Graham et al. (2016) proposed a unified theoretical model to analyze the three main types of political risk (war, expropriation, and transfer restrictions); the heterogeneity of government constraints to determine effective strategies to manage political risk. In general, in order to make the risk assessment results intuitive, scholars tend to use mathematical methods to achieve risk quantification.

\section{(c) Research on Risk Management Measures}

Political risk not only comes from many factors but also causes serious losses. Dealing with political risk in a comprehensive way is beneficial to the development of the company in many aspects (Stevens et al., 2016). Foreign investment will inevitably encounter political risk (Kesternich and Schnitzer, 2010; Li and Liang, 2012; Mocan and Raschke, 2016), but political risk is not uncontrollable (Puck et al., 2013; Kingsley \& Vanden Bergh, 2015; Mellahi et al., 2016). Therefore, taking reasonable and practical management measures is also the focus of scholars. The existing articles mainly put forward feasible management measures from the perspective of multinational enterprises. Cosset and Suret (1995) pointed out that the inclusion of a country with high political risk in a portfolio can reduce overall investment risk. Ullah et al. (2019) argued that companies should choose a management strategy based on their exposure. Companies with limited exposure should seek low-cost strategies, while companies with higher exposures should choose resource-intensive strategies. Keillor et al. (2005) found that companies emphasize the use of industry alliances to reduce the risk of transfer restrictions. When ownership/control restrictions were threatened, managers were most inclined to lobby for industry alliances and host countries. When political threats emerge in the form of confiscation of income, the efforts of individual companies in the context of host country lobbying are important. Ling and Hoang (2009) recommend that foreign companies invest in construction projects in Vietnam by providing anticorruption training to employees stationed in Vietnam; undertaking short-term projects; using local partners for approval, and licensing; and purchasing political risk insurance to overcome political risk. Deng et al. (2014b) proposed that establishing a lasting and stable relationship with the host government is an effective mitigation measure to deal with political risks. Meanwhile, it should be noted that too close a relationship with the host government will make international contractors more vulnerable to political instability. Chang et al. (2018b) identified 27 strategies for political risk management through literature overview and questionnaire survey. Using exploratory factor analysis, these 27 strategies are classified into 6 parts :(1) making the right decision, (2) conducting favorable negotiation, (3) completing sufficient preparation, (4) forming a pleasant environment, (5) reducing unnecessary mistakes, and (6) getting a reasonable response.

\subsection{Research regarding Political Risk in International construction projects}

Political risk has always been a hot issue that multinational corporations cannot avoid in international expansion. The characteristics of political risk include many sources of risk, serious losses caused by risk and challenges. As the global economic recession accelerates the trend of state intervention in the market and the intertwining of traditional and non-traditional factors, political risk presents a trend of high, destructive, and sophisticated development. The political risks faced by multinational corporations are broader and more complicated than in the past, and their forms are more diverse (Jakobsen, 2010). The characteristics of international construction projects, such as long cycle, multiple partners from different countries, diversity of management modes and technical standards, and international payment methods, put it in greater contact with the international and host country environment, and thus it is more deeply and extensively affected by environmental changes. Among the risks caused by political, economic, and social events, political risk is one of the most risk-free types of international construction projects (Guo et al., 2014). Because the political environment in host countries varies widely, for international contractors, the political risk of the host country is a type of risk that is very unfamiliar. Coupled with the serious consequences of political risk and the difficulty of active control (Ashley and Bonner, 1987), political risk is extremely damaging to international contractors. Therefore, it is necessary to study the political risk of international construction projects. 
Most of the scholars' research on political risk is about transnational investment and trade. In general, there are few studies on the political risk of international construction projects. Since international construction project contracts are a kind of international technology trade and a comprehensive international investment cooperation mode, the political risk characteristics of international construction projects and transnational investment are very similar. The research on political risk in transnational investment is also helpful in analyzing the political risk of international construction projects. Based on the above research status of political risk, the author proposed several future research directions regarding the political risk of international construction projects.

\section{(a) Research on the impact of the political risk should be refined}

Scholars had done lots of research on the impact of political risk on foreign investment. Previous studies had shown that the impact of political risk on foreign investment might be positive or negative, and foreign investment might be affected by other risk factors. As a comprehensive international investment cooperation mode, an international project has its own characteristics and the environment will be different. Therefore, when studying the impact of political risk on investment, it is necessary to refine further the impact of political risk on the location selection, entry mode, and corporate performance of international construction projects contracting enterprises.

\section{(b) Quantitative risk assessment should be optimized}

When conducting risk assessments, most scholars use different methods to quantify the risks, making the results of the evaluation more intuitive. However, over-reliance on a mathematical model of precise computation can also have drawbacks. In some studies of management, some information is difficult to quantify, or there is considerable subjectivity in the quantification, which leads to insufficient data and poor representation. So, it is impossible to obtain reliable conclusions. At the same time, when assessing the potential impact of political risk, it is necessary to distinguish between different types of stakeholders and how these stakeholders are affected by different political measures (Kesternich and Schnitzer, 2010) and the accuracy of the data (Nelson et al., 2016). The existing political risk assessment system is subjective, and many methods are reflective, not forward-looking, and there are problems such as difficulty in data acquisition and lag in evaluation (Al Khattab et al., 2007). In order to minimize the impact of subjective factors and inaccurate data on the evaluation results, artificial intelligence methods such as evidence theory and cloud model can be introduced on the basis of traditional risk assessment methods to accurately and quantitatively explain the qualitative concepts in the evaluation process and improve the accuracy of evaluation.

\section{(c) The research perspective of risk management measures should be broadened}

At present, the management measures of political risk are mainly focused on the enterprise level. There is a lack of discussion on the influence of micro individuals on the enterprise risk decision-making and macro factors on the balance of political risk in the host country. The perception of political risk by executives is important for political risk management. The characteristics of executives will influence the choice of entry modes in overseas markets. The role of personal executive characteristics in political risk management needs to be further explored. At the macro level, checks and balances on the opportunistic behavior of the host country come not only from the host country but also from bilateral relations or the degree of the host country's participation in globalization. Hence, future studies can further broaden the perspective to study the influence of micro individuals on enterprise risk decisions and the role of macro factors in balancing political risks in host countries.

\subsection{Limitations}

The research methods of this study have certain limitations. Firstly, this study uses the visual analysis method (CiteSpace) to scientifically analyze the research status, knowledge base, and research hotspots of political risk. The results are objective and credible. However, because the operation of CiteSpace is limited by the software extraction information and analysis information algorithms and functions, it will affect the accuracy of the data results to a certain extent, resulting in slight deviations from research hotspots and frontiers. Secondly, this article selected only the articles in the WoS database, and some related articles are not covered, resulting in incomplete analysis content. In order to fully understand the relevant research on political risk, it is necessary to analyze all relevant articles in WoS and even other databases (SCOPUS, etc.).

\section{Conclusions}

In the past few decades, the academic community has carried out relatively abundant research on political risk and published a large amount of literature. Using visual analysis combined with content analysis, the research on political risk was summarized based on the publications extracted from WoS from 1965 to 2020 (December). According to the overview of existing literature, research overview (Country, Institution, Author analysis) 、knowledge base (Reference、Cited Author、Cited Journal analysis), hotspots and trends (Keyword analysis) in the field of political risk were summarized. Based on keyword analysis, using the content analysis method, this overview selected three critical aspects of political risk research for detailed analysis. However, while scholars have achieved fruitful results in political risk research, the research results for international 
construction projects are few. Based on the existing literature on political risk research for all companies, this overview put forward some suggestions for the study of political risk in international construction projects for reference: 1) Materialize research on the impact of political risks; 2) Optimize the quantitative evaluation of risk; 3 ) Broaden research perspective of risk management measures. The contributions of the paper to the literature are as follows. Firstly, CiteSpace was used to analyze the current research status of political risk and future research directions. Compared to the existing political risk literature overview, this overview uses a set of knowledge maps to show trends in political risk research. The research results enrich the methods of visual analysis and expand the types of literature overview. The method can also be applied to other fields to help researchers master the evolution of specific areas. Secondly, by analyzing 978 articles on political risk in WoS from 1965 to 2020, this overview draws on the important countries, institutions, authors, articles, journals, etc. that play an important role in political risk research, as well as important research issues and their evolution trends in this field. It provides scholars with a convenient way to fully understand the field, which is conducive to scholars to propose valuable research directions. Third, based on the analysis results, this paper proposes three aspects of the study of political risk in international construction projects that need to be perfected and that we hope to be solved in future research.

\section{Acknowledgments}

The authors acknowledge the team for creating and managing the software CiteSpace that has been so helpful in writing this article.

\section{Funding details}

This study was supported by China National Science Foundation (Grant No. 71771052) and Key Consulting and Research Project of Chinese Academy of Engineering - Strategic Study on China's Construction 2035 (Grant No. 2019-xz-029).

\section{Disclosure statement}

No potential conflict of interest was reported by the authors.

\section{Ethical approval}

This article does not contain any studies with human participants or animals performed by any of the authors.

\section{References}

Al Khattab, A., Anchor, J., \& Davies, E. (2007). Managerial perceptions of political risk in international projects. International Journal of Project Management, 25(7), 734-743.

Alamgir, M., Campbell, M. J., Sloan, S., Goosem, M., Clements, G. R., Mahmoud, M. I., \& Laurance, W. F. (2017). Economic, socio-political and environmental risks of road development in the tropics. Current Biology, 27(20), R1130-R1140.

Aliber, R.Z. (1975). Exchange risk, political risk, and investor demand for external currency deposits. Journal of Money, Credit and Banking, 7(2), 161-179.

Al-Khouri, R. (2015). Determinants of foreign direct and indirect investment in the MENA region. The Multinational Business Review, 23(2), 148-166.

Ashley, D.B., \& Bonner, J.J. (1987). Political risks in international construction. Journal of Construction Engineering and Management, 113(3), 447-467.

Bekaert, G., Harvey, C.R., Lundblad, C.T., \& Siegel, S. (2014). Political Risk Spreads. Journal of International Business Studies, 45(4), 471-493.

Boutchkova, M., Doshi, H., Durnev, A., \& Molchanov, A. (2012). Precarious politics and return volatility. The Review of Financial Studies, 25(4), 1111-1154.

Buckley, P.J., Clegg, L.J., Cross, A., Liu, X., Voss, H., \& Zheng, P. (2010). The determinants of Chinese outward foreign direct investment. in Foreign Direct Investment, China and the World Economy. Springer), 81-118.

Bunyaratavej, K., \& Hahn, E. D. (2007, June). Outward foreign direct investments from China: Theory and determinants. In AIB 2007 Annual Meeting, Indianapolis (pp. 25-28).

Busse, M. (2004). Transnational corporations and repression of political rights and civil liberties: An empirical analysis. Kyklos, 57(1), 45-65.

Chang, T., Deng, X., Zuo, J., \& Yuan, J. (2018a). Political Risks in Central Asian Countries: Factors and Strategies. Journal of Management in Engineering, 34(2), 04017059.

Chang, T., Hwang, B.-G., Deng, X., \& Zhao, X. (2018b). Identifying political risk management strategies in international construction projects. Advances in Civil Engineering, 2018.

Chen, C. (2006). CiteSpace II: Detecting and visualizing emerging trends and transient patterns in scientific literature. Journal of the American Society for Information Science and Technology, 57(3), 359-377.

Chen, C. (2014). CiteSpace II: Detecting and visualizing emerging trends and transient patterns in scientific literature. Journal of the Association for Information Science \& Technology, 57(3), 359-377. 
Cosset, J.-C., \& Suret, J.-M. (1995). Political risk and the benefits of international portfolio diversification. Journal of International Business Studies, 26(2), 301-318.

Cronin, B. (2001). Bibliometrics and beyond: some thoughts on web-based citation analysis. Journal of Information Science, 27(1), 1-7.

Dandage, R.V., Mantha, S.S., \& Rane, S.B. (2019). Strategy development using TOWS matrix for international project risk management based on prioritization of risk categories. International Journal of Managing Projects in Business, 12(4), 1003-1029.

Davies, M. (2015). The Use of Arbitration in Loan Agreements in International Project Finance: opening Pandora's Box or an Unexpected Panacea? Izvestiya Akademii Nauk.ser.fizicheskaya, 51(51), 330-339.

Deng, X., Low, S.P., Li, Q., \& Zhao, X. (2014a). Developing competitive advantages in political risk management for international construction enterprises. Journal of Construction Engineering and Management, 140(9), 04014040.

Deng, X., Low, S.P., Zhao, X., \& Chang, T. (2018). Identifying micro variables contributing to political risks in international construction projects. Engineering, Construction and Architectural Management, 25(3), 317-334.

Deng, X., Pheng, L.S., \& Zhao, X. (2014b). Project System Vulnerability to Political Risks in International Construction Projects: The Case of Chinese Contractors. Project Management Journal, 45(2), 20-33.

Dinar, A., Balakrishnan, T.K., \& Wambia, J. (2004). Politics of institutional reforms in the water and drainage sector of Pakistan. Environment and Development Economics, 9(3), 409-445.

Duan, F., Ji, Q., Liu, B.-Y., \& Fan, Y. (2018). Energy investment risk assessment for nations along China’s Belt \& Road Initiative. Journal of Cleaner Production, 170, 535-547.

Duanmu, J.-L. (2012). Firm heterogeneity and location choice of Chinese multinational enterprises (MNEs). Journal of World Business, 47(1), 64-72.

Duanmu, J.-L., \& Guney, Y. (2009). A panel data analysis of locational determinants of Chinese and Indian outward foreign direct investment. Journal of Asia Business Studies, 3(2), 1-15.

Easterly, W., Levine, R., \& Roodman, D. (2004). Aid, Policies, and Growth: Comment. American Economic Review, 94(3), 774-780.

Gao, W., \& Hong, K. (2017). The portfolio balanced risk index model and analysis of examples of large-scale infrastructure project. Complexity 2017.

Graham, B. A., Johnston, N. P., \& Kingsley, A. F. (2016). A Unified Model of Political Risk. Advances in Strategic Management, In Strategy beyond markets, 34, 119-160.

Guo, J.j., Wang, G.C., \& Tung, C.h. (2014). Do China's outward direct investors prefer countries with high political risk? An international and empirical comparison. China \& World Economy, 22(6), 22-43.

Hajzler, C. (2014). Resource-based FDI and expropriation in developing economies. Journal of International Economics 92(1), 124-146.

Haner, F. (1979). Rating investment risks abroad. Business Horizons 22(2), 18-23.

Herrero, A., Corchado, E., \& Jimenez, A. (2011). Unsupervised neural models for country and political risk analysis. Expert Systems With Applications, 38(11), 13641-13661.

Holburn, G.L., \& Zelner, B.A. (2010). Political capabilities, policy risk, and international investment strategy: Evidence from the global electric power generation industry. Strategic Management Journal, 31(12), 1290-1315.

Hood, J., \& Nawaz, M.S. (2004). Political risk exposure and management in multinational companies: is there a role for the corporate risk manager? Risk Management, 6(1), 7-18.

Hox, J.J., \& Boeije, H.R. (2005). Data Collection, Primary vs. Secondary. Encyclopedia of Social Measurement, 1, $593-599$.

Hu, W., Li, C.-h., Ye, C., Wang, J., Wei, W.-w., \& Deng, Y. (2019). Research progress on ecological models in the field of water eutrophication: CiteSpace analysis based on data from the ISI web of science database. Ecological Modelling, 410, 108779.

Jadhav, P. (2012). Determinants of foreign direct investment in BRICS economies: Analysis of economic, institutional and political factor. Procedia-Social and Behavioral Sciences, 37, 5-14.

Jakobsen, J. (2010). Old problems remain, new ones crop up: Political risk in the 21st century. Business Horizons, 53(5), 481490.

Javed, S. A., \& Liu, S. (2018). Predicting the Research Output/Growth of Selected Countries: Application of Even GM (1, 1) and NDGM Models. Scientometrics, 115(1), 395-413.

Jensen, N. (2008). Political risk, democratic institutions, and foreign direct investment. The Journal of Politics, 70(4), 10401052.

Jia, R., Li, Q., Deng, X., Zhao, X., \& Yuan, J. (2017). Entry Mode Taxonomy and Choice of Chinese International Construction Companies. Journal of Management in Engineering, 33(3), 04016058.

Jiang, W., Martek, I., Hosseini, M.R., Tamošaitienė, J., \& Chen, C. (2019). Foreign infrastructure investment in developing countries: a dynamic panel data model of political risk impacts. Technological and Economic Development of Economy, 25(2), 134-167.

Jiménez, A. (2010). Does political risk affect the scope of the expansion abroad? Evidence from Spanish MNEs. International Business Review, 19(6), 619-633.

Jiménez, A. (2011). Political risk as a determinant of Southern European FDI in neighboring developing countries. Emerging Markets Finance and Trade, 47(4), 59-74.

Jiménez, A., \& Alon, I. (2018). Corruption, political discretion and entrepreneurship. Multinational Business Review, 26(2), 
111-125.

Jiménez, A., Luis-Rico, I., \& Benito-Osorio, D. (2014). The influence of political risk on the scope of internationalization of regulated companies: Insights from a Spanish sample. Journal of World Business, 49(3), 301-311.

Jiménez, A., Russo, M., Kraak, J.M., \& Jiang, G.F. (2017). Corruption and private participation projects in Central and Eastern Europe. Management International Review, 57(5), 775-792.

Jiménez, A., Salvaj, E., \& Lee, J.Y. (2018). Policy risk, distance, and private participation projects in Latin America. Journal of Business Research, 88, 123-131.

Jones, G., \& Comunale, R. (2018). Business, Governments and Political Risk in South Asia and Latin America since 1970. Australian Economic History Review 58(3), 233-264.

Kang, Y., \& Jiang, F. (2012). FDI location choice of Chinese multinationals in East and Southeast Asia: Traditional economic factors and institutional perspective. Journal of World Business, 47(1), 45-53.

Kassicieh, S.K., \& Nassar, J.R. (1982). Political risk and the multinational corporation: a study of the impact of the Iranian Revolution on Saudi Arabia, Kuwait and the United Arab Emirates. Management International Review, 22(3), 22-32.

Keillor, B.D., Wilkinson, T.J., \& Owens, D. (2005). Threats to international operations: dealing with political risk at the firm level. Journal of Business Research, 58(5),629-635.

Kesternich, I., \& Schnitzer, M. (2010). Who is afraid of political risk? Multinational firms and their choice of capital structure. Journal of International Economics, 82(2), 208-218.

Kim, D.Y., Han, S.H., \& Kim, H. (2008). Discriminant Analysis for Predicting Ranges of Cost Variance in International Construction Projects. Journal of Construction Engineering and Management-asce, 134(6), 398-410.

Kingsley, A.F., \& Vanden Bergh, R. (2015). How regulatory uncertainty drives integrated market and non-market strategy. The Routledge Companion to Non-market Strategy. Routledge, 47-65.

Kluge, J.N. (2017). Foreign direct investment, political risk and the limited access order. New Political Economy, 22(1), 109127.

Kolstad, I., \& Wiig, A. (2012). What determines Chinese outward FDI? Journal of World Business, 47(1), $26-34$.

Lee, C.-Y. (2016). Terrorism, counterterrorism aid, and foreign direct investment. Foreign Policy Analysis, 13(1), $168-187$.

Li, H., Sun, R., Lee, W.-J., Dong, K., \& Guo, R. (2016). Assessing risk in Chinese shale gas investments abroad: Modelling and policy recommendations. Sustainability, 8(8), 708.

Li, Q. (2009). Democracy, Autocracy, and Expropriation of Foreign Direct Investment. Comparative Political Studies, 42(8), 1098-1127.

Li, Q., \& Liang, G. (2012). Political relations and Chinese outbound direct investment: Evidence from firm-and dyadic-level tests. Research Center for Chinese Politics and Business Working Paper (19).

Li, Q., \& Vashchilko, T. (2010). Dyadic military conflict, security alliances, and bilateral FDI flows. Journal of International Business Studies, 41(5), 765-782.

Ling, F.Y.Y., \& Hoang, V.T.P. (2009). Political, economic, and legal risks faced in international projects: Case study of Vietnam. Journal of Professional Issues in Engineering Education and Practice, 136(3), 156-164.

López-Duarte, C., \& Vidal-Suárez, M.M. (2010). External uncertainty and entry mode choice: Cultural distance, political risk and language diversity. International Business Review, 19(6), 575-588.

Maemura, Y., Kim, E., \& Ozawa, K. (2018). Root Causes of Recurring Contractual Conflicts in International Construction Projects: Five Case Studies from Vietnam. Journal of Construction Engineering and Management-asce, 144(8), 05018008.

Malhotra, S., \& Zhu, P. (Year). Determinants and valuation impact of cross-border acquisitions by firms from China and India. in: AIB Conference).

Mazher, K.M., Chan, A.P., Zahoor, H., Khan, M.I., \& Ameyaw, E.E. (2018). Fuzzy Integral-Based Risk-Assessment Approach for Public-Private Partnership Infrastructure Projects. Journal of Construction Engineering and Management 144(12), 04018111.

Mellahi, K., Frynas, J.G., Sun, P., \& Siegel, D. (2016). A review of the nonmarket strategy literature: Toward a multi-theoretical integration. Journal of Management, 42(1), 143-173.

Mocan, N., \& Raschke, C. (2016). Economic well-being and anti-Semitic, xenophobic, and racist attitudes in Germany. European Journal of Law and Economics, 41(1), 1-63.

Mohammad, et al. "Political risk and bank stability in the Middle East and North Africa region." Pacific-Basin Finance Journal 60.

Nelson, M.M., Sooreea, R., \& Gokcek, G. (2016). The FDI-political risk nexus: some new insights. The Business \& Management Review, 7(5), 33.

Oetzel, J. (2005). Smaller may be beautiful but is it more risky? Assessing and managing political and economic risk in Costa Rica. International Business Review, 14(6), 765-790.

Onwuegbuzie, A.J., Johnson, R.B., \& Collins, K.M. (2009). Call for mixed analysis: A philosophical framework for combining qualitative and quantitative approaches. International Journal of Multiple Research Approaches, 3(2), 114-139.

Owolabi, H.A., Oyedele, L.O., Alaka, H.A., Ebohon, O.J., Ajayi, S.O., Akinade, O.O., et al. (2019). Public private partnerships (PPP) in the developing world: Mitigating financiers' risks. World Journal of Science, Technology and Sustainable Development, 16(3), 121-141.

Pan, W., Jian, L., \& Liu, T. (2019). Grey system theory trends from 1991 to 2018: a bibliometric analysis and visualization. Scientometrics, 121(3), 1407-1434. 
Puck, J.F., Rogers, H., \& Mohr, A.T. (2013). Flying under the radar: Foreign firm visibility and the efficacy of political strategies in emerging economies. International Business Review, 22(6), 1021-1033.

Ramamurti, R. (2001). The obsolescing 'bargaining model'? MNC-host developing country relations revisited. Journal of International Business Studies, 32(1), 23-39.

Ramasamy, B., Yeung, M., \& Laforet, S. (2012). China's outward foreign direct investment: Location choice and firm ownership. Journal of World Business, 47(1), 17-25.

Robock, S.H. (1971). Political risk-identification and assessment. Columbia Journal of World Business, 6(4), 6-20.

Root, F.R. (1972). Analyzing political risks in international business. Darwin Press: Princeton, NJ.

Sauvant, K.P. (2015). Attracting Foreign Direct Investment and Benefiting from it: Challenges for the Least Developed Countries. Transnational Corporations Review, 7(2), 125-127.

Song, T., Wei, L., Li, Y., \& Sun, W. (2010, August). Application of Fuzzy Comprehensive Evaluation Method in Selecting Logistics Service Provider. In 2010 International Conference on Internet Technology and Applications (pp. 1-4). IEEE.

Sottilotta, C.E. (2015). Political risk assessment and the Arab Spring: What can we learn? Thunderbird International Business Review, 57(5), 379-390.

Stevens, C.E., Xie, E., \& Peng, M.W. (2016). Toward a legitimacy-based view of political risk: The case of Google and Yahoo in China. Strategic Management Journal, 37(5), 945-963.

Tsai, M.-C., \& Su, C.-H. (2005). Political risk assessment of five East Asian ports - the viewpoints of global carriers. Marine Policy, 29(4), 291-298.

Ullah, S., Deng, X., \& Chang, T. (2019). Forming Mechanism of Political Risks in International Construction Projects: From the Perspective of Chinese Contractors. Frontiers in Built Environment, 5, 101.

Wang (2020) Research Progress and Development Trend of Social Media Big Data (SMBD): Knowledge Mapping Analysis Based on CiteSpace

Wei, S. J. (2000). How taxing is corruption on international investors?. Review of Economics and Statistics, 82(1), 1-11.

Yasuda, N., \& Kotabe, M. (2020). Political risks and foreign direct investments by multinational corporations: A reference point approach. Global Strategy Journal. https://doi.org/10.1002/gsj.1380

Zhao, X., \& Singhaputtangkul, N. (2016). Effects of firm characteristics on enterprise risk management: Case study of Chinese construction firms operating in Singapore. Journal of Management in Engineering 32(4), 05016008.

Zhao, X., Wu, P., \& Wang, X. (2018). Risk paths in BIM adoption: empirical study of China. Engineering, Construction and Architectural Management 25(9), 1170-1187.

Zhuang, L., Ritchie, R., \& Zhang, Q. (1998). Managing business risks in China. Long Range Planning, 31(4), 606-614.

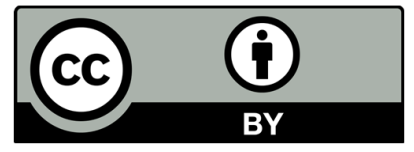

(C) 2020 by the authors; licensee Growing Science, Canada. This is an open access article distributed under the terms and conditions of the Creative Commons Attribution (CC-BY) license (http://creativecommons.org/licenses/by/4.0/). 